\title{
ОСОБЛИВОСТІ ПРИТЯГНЕННЯ ВІЙСЬКОВОСЛУЖБОВЦІВ ДО ВІДПОВІДАЛЬНОСТІ ЗА ВЧИНЕННЯ ВІЙСЬКОВИХ АДМІНІСТРАТИВНИХ ПРАВОПОРУШЕНЬ
}

\begin{abstract}
ПОДОЛЯКА Анатолій Миколайович - доктор юридичних наук, професор, Заслужений юрист України, завідувач кафедри теорії держави і права та конституційного права ПрАТ «ВНЗ «Міжрегіональна Академія управління персоналом".

ДЬОМІН Юрій Михайлович - доктор юридичних наук, професор, Заслужений юрист України, адвокат.
\end{abstract}

DOI 10.32782/LAW.UA.2021.3.9

В статъе идет речь об особенностях привлечения виновнъгх в совершении военнъхх административнъгх правонарушений к административной ответственности, а также о возможности расширения круга субъектов, которьм будет предоставлено право составления протоколов о военнъгх административньх правонарушениях. Подчеркнуто, что военнъие административнъие правонарушения характеризуются наличием умылла, неосторожности, а также и смешанной бормой винъ, в зависимости от состава проступка.

Акцентировано внимание на создании нового правоохранительного органа - Военной поличии. Отмечено, что бъттует мнение о том, ито после создания военной полиции более оперативно и эбббективно будет проведено досудебное расследование многих преступлений и проступков в военной сфере, особенно в зоне проведения Операции Объединеннъх Сил (ООС). Проведен системный анализ предложений к законопроекту и въделен ряд задач, которье будут выполняться Военной полищиeй.

Ключевъе слова: военнъие прокурорьи, военное административное правонарушение, Военная полииия.

Постановка проблеми

Відповідно до статті 131-1 Конституції України в Україні діє прокуратура, яка здійснює представницькі повноваження у передбачених законом випадках [1].

Право.ua № 3, 2021
Статус прокурора визначений статтею 15 Закону України «Про прокуратуру» 3 урахуванням спеціалізації органів військової прокуратури.

Згідно з частиною 7 ст. 23 Закону України «Про прокуратуру» під час здійснення представницьких повноважень прокурор у разі встановлення ознак адміністративного правопорушення зобов'язаний здійснити передбачені законом дії щодо порушення відповідного провадження [2].

Відповідно до пункту 11 частини першої ст. 255 Кодексу України про адміністративні правопорушення (далі - КУпАП) прокурор уповноважений складати протоколи про вчинення військових адміністративних правопорушень, передбачених ст. ст. $172^{10}-$ $172^{20}$ КУПАП.

Порядок провадження у справах про адміністративні правопорушення, е тому числі у справах? передбачених «Главою 13 - Б» КУПАП, визначається відповідно до цього Кодексу та інших законів України [3, ст.246].

Частиною 1 статті 250 КУпАП передбачено, що прокурор, заступник прокурора, здійснюючи нагляд за додержанням і правильним застосуванням законів при провадженні в справах про адміністративне правопорушення? має право: порушувати провадження в справі про адміністративне правопорушення; знайомитися 3 матеріалами справи; перевіряти законність дій органів (посадових осіб) при провадженні в справі; брати участь у розгляді справи; заявляти 
клопотання; давати висновки 3 питань, що виникають під час розгляду справи; перевіряти правильність застосування відповідними органами (посадовими особами) заходів впливу за адміністративні правопорушення; вносити подання, оскаржувати постанову i рішення по скарзі в справі про адміністративне правопорушення, а також вчиняти інші передбачені законом дії [3].

\section{Стан дослідження проблеми}

Різноманітні проблеми діяльності органів прокуратури їх правового статусу, як органів, які наділені правом представництва прав, свобод та інтересів громадян, були предметом наукового пошуку таких дослідників, як: О. М. Бандурка, А. Р. Грицаєнко, Ю. М. Грошевий, Л. М. Давиденко, В. В. Долежан, П. М. Каркач, М. В. Косюта, М. Й. Курочка, І. Е. Марочкін, О. Р. Михайленко, М. І. Мичко, Е. М. Попович, Н. О. Рибалка, М. В. Руденко, В. В. Сухонос, В. Я. Тацій, Ю. М. Тодика, Ю. С. Шемшученко, П. В. Шумський, М. К. Якимчук та багатьох інших.

Метою статті $є$ аналіз особливостей притягнення військовослужбовців до відповідальності за вчинення військових адміністративних правопорушень.

\section{Виклад основного матеріалу}

Підставами притягнення особи до адміністративної відповідальності є вчинення нею адміністративного правопорушення (проступку), яким згідно зі ст. 9 КУпАП визнається протиправна, винна (умисна або необережна) дія чи бездіяльність, яка посягає на громадський порядок, власність, права і свободи громадян, на встановлений порядок управління і за яку законом передбачено адміністративну відповідальність.

Адміністративне правопорушення визнається вчиненим:

- умисно, коли особа, яка його вчинила, усвідомлювала протиправний характер своєї дії чи бездіяльності, передбачала іiі шкідливі наслідки і бажала їх або свідомо допускала настання цих наслідків;

- 3 необережності, коли особа, яка його вчинила, передбачала можливість настання шкідливих наслідків своєї дії чи бездіяльності, але легковажно розраховувала на їх відвернення або не передбачала можливості настання таких наслідків, хоч повинна була і могла їх передбачити [3, ст. ст. 10, 11].

Військові адміністративні правопорушення характеризуються наявності умислу, необережності так і змішаною виною, у залежності від складу проступку.

Слід враховувати, що в усіх статтях Глави 13-Б КУпАП мова йде про військовослужбовців, військовозобов'язаних або спеціальних суб'єктів окремих складів військових адміністративних правопорушень.

Зокрема у статтях $172^{13}-172^{16}$ КУпАП під військовими службовими особами розуміються військові начальники, а також інші військовослужбовці, які обіймають постійно чи тимчасово посади, пов'язані з виконанням організаційно-розпорядчих чи адміністративно-господарських обов' язків, або виконують такі обов'язки за спеціальним дорученням повноважного командування.

До відповідальності за вчинення адміністративного правопорушення, передбаченого ст. $172^{11}$ КУпАП, може бути притягнуто лише військовослужбовця строкової військової служби.

У статті $172^{17}$ КУпАП суб'єктом правопорушення є військовослужбовці, які входять до складу чергових сил бойового чергування, а статті $172^{18}$ КУпАП - лише військовослужбовці, які входять до складу наряду 3 охорони державного кордону України.

Окрім зазначеного, особливістю статей $172^{11}$ та $172^{20}$ КУпАП є передбачена законодавцем кваліфікуюча ознака повторності впродовж року вчинення аналогічного адміністративного правопорушення, за яку передбачено більш суворе адміністративне стягнення.

Військовослужбовець вважається підданим адміністративному стягненню, якщо щодо нього встановленим порядком складався протокол про вчинення адміністративного правопорушення (ст. ст. $172^{11}$ та $172^{20}$ КУпАП), за яким судом прийнято рішення про накладення стягнення. Статтею 294 КУпАП передбачено, що постанова суду набирає законної сили після закінчення строку подання апеляційної скарги, тоб- 


\section{Кримінальне право, кримінальний процес та криміналістика}

то протягом 10 днів 3 дня ії винесення або винесення постанови за результатами розгляду апеляційної скарги. 3 цього моменту особа вважається такою, що притягнута до адміністративної відповідальності.

Слід також враховувати, що за правилами ст. 15 КУПАП військовослужбовці, військовозобов'язані та резервісти під час проходження зборів, а також особи рядового і начальницького складів Державної кримінально-виконавчої служби України, служби цивільного захисту і Державної служби спеціального зв'язку та захисту інформації України, поліцейські несуть відповідальність за адміністративні правопорушення за дисциплінарними статутами [3, ч.1 ст.15].

У той же час за інші, не передбачені Главою 13-Б КУпАП адміністративні делікти ці особи несуть адміністративну відповідальність на загальних підставах. До них не може бути застосовано громадські та виправні роботи, адміністративний арешт [3, ч.2 ст.15].

Відповідно до ст. 39 КУПАП, якщо особа, піддана адміністративному стягненню, протягом року з дня закінчення виконання стягнення не вчинила нового адміністративного правопорушення, то ця особа вважається такою, що не була піддана адміністративному стягненню.

Чинники, які необхідно враховувати під час притягнення особи до відповідальності за вчинення військових адміністративних правопорушень:

1) наявність у винної особи статусу військовослужбовця, а також спеціального суб'єкта окремих складів адміністративних правопорушень;

2) відсутність у діях (бездіяльності) правопорушника ознак кримінально караного діяння.

3) наявність у діях (бездіяльності) військовослужбовця складу адміністративного правопорушення, передбаченого відповідними статтями глави 13-Б КУпАП;

4) наявність чи відсутність ознаки повторності при скоєнні адміністративних правопорушень, передбачених ст. ст. $172^{11}$ та $172^{20}$ КУпАП;

5) дотримання передбачених ст. 38 КУпАП строків притягнення винної особи до адміністративної відповідальності [4].
Зокрема частинами 2 і 4 статті 38 КУпАП передбачено, що якщо справи про адміністративні правопорушення відповідно до цього Кодексу чи інших законів підвідомчі суду (судді), стягнення може бути накладено не пізніше як через три місяці з дня вчинення правопорушення, а при триваючому правопорушенні - не пізніш як через три місяці з дня його виявлення, крім справ про адміністративні правопорушення, зазначених у частині третій цієї статті. Адміністративне стягнення за вчинення правопорушення, пов'язаного 3 корупцією, а також правопорушень, передбачених статтями 164-14, 212-15, 212-21 Кодексу України про адміністративні правопорушення, може бути накладено протягом трьох місяців 3 дня його виявлення, але не пізніше двох років 3 дня його вчинення [3, ст. 38].

У разі закриття кримінального провадження, але за наявності в діях порушника ознак адміністративного правопорушення, адміністративне стягнення може бути накладено не пізніше як через місяць 3 дня прийняття рішення про закриття кримінального провадження [3, ст.38].

6) наявність обставин, що виключають адміністративну відповідальність за вчинене правопорушення, зокрема, чи не діяла особа у стані крайньої необхідності або необхідної оборони тощо [3, ст. ст. 17 - 20].

Ініціювання притягнення військовослужбовців до адміністративної відповідальності за вчинення військових адміністративних правопорушень здійснюється уповноваженими працівниками військових прокуратур відповідно до принципу територіальності вчинення правопорушення, незалежно від підпорядкування правопорушників різновиду військового формування чи виду Збройних Сил України.

У разі виявлення прокурором військового адміністративного правопорушення, вчиненого військовослужбовцем у територіальних межах відповідальності іншої військової прокуратури, належить повідомити про це відповідного військового прокурора [4].

В останній час активізувалася діяльність щодо створення нового правоохоронного органу - Військової поліції. 3 назви органу зрозуміло, що ця поліція повинна діяти саме у військовій сфері. 
Поняття «поліція» вивчалося багатьма науковцями досить тривалий час і ще до створення такого органу в нас у державі. Зокрема, у збірнику Міжнародна поліцейська енциклопедія надається декілька понять поліції та пов'язаних із ним поняттями [5].

Ряд правоохоронців запевняє, що після створення військової поліції оперативніше й ефективніше буде проведено досудове розслідування багатьох злочинів та проступків у військовій сфері, а особливо в зоні проведення Операції Об'єднаних Сил ( ООС).

Якщо провести системний аналіз пропозицій до законопроєкту, то можна виділити ряд завдань, які буде виконуватиме Військова поліція, зокрема:

- запобігання вчиненню, виявлення i припинення злочинів та інших правопорушень у Міністерстві оборони, 3бройних Силах, правоохоронних органах спеціального призначення та інших військових формуваннях;

- досудове розслідування злочинів та кримінальних проступків, пов'язаних з проходженням військової служби, вчинених військовослужбовцями, а так само корупційних злочинів, вчинених працівниками та державними службовцями Міністерства оборони і Збройних Сил;

- виявлення причин, передумов та обставин злочинів та інших правопорушень;

- проведення оперативно-розшукової діяльності;

- виконання рішень про тримання військовослужбовців на гауптвахті, у кімнатах тимчасово затриманих, спеціальних палатах закладів охорони здоров'я Міністерства оборони;

- забезпечення виконання кримінального покарання стосовно військовослужбовців, які вироком суду засуджені до тримання у дисциплінарному батальйоні;

- участь у припиненні протиправних дій цивільних осіб на територіях військових частин, військових навчальних закладів, установ та організацій Міністерства оборони та Збройних Сил, військових містечок Міністерства оборони та Збройних Сил;

- проведення у межах компетенції службових розслідувань;
- захист майна 3бройних Сил від розкрадання та інших злочинних посягань;

- забезпечення безпеки дорожнього руху військових транспортних засобів Збройних Сил;

- захист прав і свобод військовослужбовців від протиправних посягань;

- участь у запобіганні диверсійним проявам та злочинам терористичної спрямованості на території військових частин;

- розшук та затримання військовослужбовців, які самовільно залишили військові частини (місця служби);

- взаємодія 3 правоохоронними органами та військовими формуваннями тощо.

Проте слід зауважити про дискусійність деяких тез законопроєкту щодо повноважень Військової поліції, зокрема, відсутність права на складання протоколів за вчинення військових адміністративних правопорушень військовослужбовцями, військовозобов' язаними та іншими, особами.

Хоча обговорення окремих положень законопроєктів до їх остаточного прийняття цілком закономірна практика. У разі виваженої дискусії законопроєкт дійсно буде більш досконалим, відповідати вимогам часу та бути зрозумілим широкому колу, однозначно розтлумаченим усіма суб'єктами його застосування.

Статтею 255 КУпАП передбачено, що органи управління Військової служби правопорядку у Збройних Силах України мають право складати протоколи про правопорушення, вчинені військовослужбовцями, військовозобов'язаними та резервістами під час проходження зборів, а також працівниками Збройних Сил України під час виконання ними службових обов'язків за конкретно переліченими статтями.

У разі реформування Військової служби правопорядку у Військову поліцію це слід врахувати.

Відповідно до пунктів 11 та 14 частини 1 статті 255 КУпАП у справах про адміністративні правопорушення, що розглядаються органами, зазначеними в статтях 218-221 цього Кодексу, протоколи про правопорушення мають право складати, зокрема:

11) прокурор (статті $172^{4}-172^{20} ; 185^{4}$; $\left.185^{8} ; 185^{11}\right)$ : 


\section{Кримінальне право, кримінальний процес та криміналістика}

14) командири (начальники) військових частин (установ, закладів), командири підрозділів, які уповноважені на те командирами (начальниками) військових частин (установ, закладів) (статті $\left.172^{10}-172^{20}\right)$.

Правом складання протоколів про адміністративних правопорушеннях у певних випадках також наділені посадови особи військової інспекції безпеки дорожнього руху військової служби правопорядку у Збройних Силах України, органів Державної прикордонної служби України, органів внутрішніх справ (Національної поліції), органів Служби безпеки України та інших правоохоронних органів [3].

На наш погляд, дуже важливим є право складання протоколів про військові адміністративні правопорушення саме прокурорами.

У 2015 році був розроблений законопроєкт № 1805, у якому сформульовані повноваження військової поліції. Згідно 3 цим законопроєктом № 1805 «Про військову поліцію» Військова поліція - військове правоохоронне формування, призначене для забезпечення правопорядку серед громадян України, які є військовослужбовцями, військовозобов'язаних та резервістів під час проходження ними зборів (далі - військовослужбовці), запобігання, виявлення кримінальних та інших правопорушень, вчинених військовослужбовцями, а також працівниками та державними службовцями Міністерства оборони України і Збройних Сил України, їх розкриття і припинення, забезпечення безпеки дорожнього руху військових транспортних засобів, захисту прав і свобод військовослужбовців та військового майна від протиправних посягань, участі у протидії диверсійним проявам i терористичним актам та припиненні протиправних дій військовослужбовців і цивільних осіб на військових об'єктах.

Відповідно до Вікіпедії Військова поліція - спеціальний правоохоронний орган 3 підтримання правопорядку в Збройних силах та інших військових і воєнізованих формуваннях, утворених відповідно до законодавства [6].

Законопроєкт № 1805 надає військовій поліції додаткові повноваження, такі як роз- слідування корупційних злочинів, вчинених державними службовцями та працівниками Міністерства оборони України та Збройних Сил України під час виконання ними службових обов'язків у розташуванні військової частини чи на військових об'єктах. Ці та інші думки щодо розширення повноважень Військової поліції на інших суб'єктів, у тому числі які працюють у військових формуваннях або в оборонному комплексі є дискусійними.

Висновки. Отож, варто підкреслити важливість створення такого правоохоронного органу. Хоча, на думку деяких учених, окремі положення законопроєкту суперечить Конституції, оскільки вони порушують статтю 17, у якій визначено, що військові формування, на відміну від поліцейських органів, ніким не можуть бути використані для обмеження прав і свобод людини. Тобто спочатку треба вносити зміни до Конституції або створювати такий підрозділ не з військових, що не зовсім доцільно [8].

Натомість, існують думки і щодо необхідності прискореного створення такого правоохоронного органу.

\section{Аітература}

1. Конституція України: прийнята на 5-й сесії Верховної Ради України 28 червня 1996 року Відомості Верховноӥ Ради Украӥни. 1996. № 30. Ст. 141.

2. Про прокуратуру: Закон України від 14.10.2014 року № 1697-VII. Відомості Верховної Ради Украйни (ВВР). 2015. № 2-3. Ст. 12.

3. Кодекс України про адміністративні правопорушення. Відомості Верховної Ради Украӥнсъкої РСР (ВВР). 1984. Додаток до№ 51. Ст. 1122.

4. Військові адміністративні правопорушення: Науково-практичний коментар глави 13-Б КУпАП / М.С.Туркот, А.В.Столітній, О.В. Міхед та ін., за ред. М. С. Туркота. 2020. $136 \mathrm{c}$

5. Міжнародна поліцейська енциклопедія. У 3-х томах. Відповідальні редактори: Римаренко Ю. І., Кондратьєв Я. Ю., Тацій В. Я., Шемшученко Ю. С. Концерн «Видавничий Дім «Ін Юре», Київ, 2005. Т. 2. С. 685-695.

6. Вікіпедія (вільна енциклопедія) (https/ uk.wikipedia.org/wiki.) 
Подоляка А.М., Дьомін Ю.М. - Особливості притягнення військовослужбовців...

\section{АНОТАЦІЯ}

у статті йдеться про особливості притягнення винних у вчиненні війсъкових адміністративних правопорушень до адміністративної відповідальності, а також про можливість розширення кола суб'єктів, яким буде надано право складання протоколів про війсъкові адміністративні правопорушення. Підкреслено, що війсъкові адміністративні правопорушення характеризуються як наявністю умислу, необережності так $і$ змішаною виною, залежно від складу проступку.

Акцентовано увагу на створенні нового правоохоронного органу - Війсъкової поліизї. Наголошено на тому, що побутує думка про те, шо після створення війсъкової полічиї оперативніше й ебективніше буде проведено досудове розслідування багатъох злочинів та проступків у війсъковій сбері, а особливо в зоні проведення Операщиї Об'єднаних Сил (ООС). Проведено системний аналіз пропозицій до законопроєкту та виділено низку завдань, які будуть виконуватися Війсъковою полічією.

Ключові слова: війсъкові прокурори, війсъкове адміністративне правопорушення, Війсъкова полічія.

7. Див. М.І. Хавронюк д.ю.н. професор. Електронний ресурс: https://www.ukrinform. ua/rubric-polytics/2814484-vijskova-policia-soce-take-ta-naviso-ukraini-ii-stvoruvati.html
The article deals with the peculiarities of bringing those guilty of military administrative offenses to administrative responsibility, as well as the possibility of expanding the range of entities that will be given the right to draw up reports on military administrative offenses. It is emphasized that military administrative offenses are characterized by the presence of intent, negligence and mixed guilt, depending on the composition of the offense.

Emphasis is placed on the creation of a new law enforcement agency - the Military Police. It is emphasized that there is an opinion that after the establishment of the military police, the pre-trial investigation of many crimes and misdemeanors in the military sphere will be conducted more quickly and efficiently, especially in the area of Operation Joint Forces (JFO). A systematic analysis of proposals for the bill was conducted and a number of tasks to be performed by the Military Police were identified.

Key words: military prosecutors, military administrative offense, Military police.

8. Дмитро Зархін (начальник управління військової прокуратури Західного регіону України, полковник юстиції). «Військова поліція: якою їй бути?» Резонанс. 22.06.2020 https://vpzhr.gp.gov.ua/ua/ guidance vpzhr.html? $\mathrm{m}=$ publications\& $\mathrm{c}=$ view\& $\mathrm{t}=\mathrm{rec} \& \mathrm{id}=275620$. 